2nd Dept. of Anat., Wakayama Med. College (Director: Prof. K. FUJIE).

\title{
Histochemical Research on the Content in the 'Productin' Vacuoles (FUJIE) of the Gastric Surface Cells. I.
}

\author{
組織化学的に見た胃粘膜表在細胞プロダクチン空胞（藤江） \\ の内容飞就て. I.

\section{Kimio FUJIE, Tatsuo YAMASHITA, Kazuko TOJYO and Ichiro YAMAGATA}

藤江君夫, 山下龍夫, 東条一子, 山形一郎.

(Received August 10, 1957.)

FUJIE, one of the authors, has previously put forward the gastric hormone productin and concluded with many experimental results that the true nature of productin must be histamine or histamine-like substance which is secreted from the gastric surface cells into the blood. His conclusion on the nature of productin, however, was obtained hitherto with experimental observations by using histamine and with quantitative determinations of histamine in the blood etc., but never in the way of chemical qualitative determination.

The authors tested various chemical colour reactions for protein and aminoacids in the vacuoles, which are seen in the subnuclear portion of the gastric surface cells. The vacuoles' content, according to FUJIE, must be very productin.

\section{Materials and Methods.}

An adult healthy dog was accustomed to the constant feeding for several days, then was killed when his stomach was empty. Small pieces were taken from the fundus and corpus ventriculi and were placed in formalin-liquid. Freezed sections of 20-30 $\mu$ were made, and the following reactions were tested.

1. The biuret reaction, 2 . the xanthoproteic reaction, 3. the MILLON's reaction, 4. the COLE's aldehyde reaction, 5. the PAULY's diazo-reaction, 6. the tetrazonium reaction, 7 . the tetrazonium reaction after the treatment by 2,4 -dinitrofluorobenzen, 8 . the same reaction after the treatment by performic acid, 9 . the same by benzoyl chloride, 10. the TOTANI's I and II reaction, 11. the HANKEKOESSLER's reaction.

The methods of these reactions will be described next in each observation.

\section{Observation and Discussion.}

a) The biuret reaction (Fig. 1). (Protein and polypeptide give a blue or reddish violet colour.)

Drop conc. $\mathrm{NaOH}$ on sections placed on a slide glass, then add $1-2$ drops of $1 \% \mathrm{CuSO}_{4}$ to it, shaking the glass. 
The sections give, generally, a very weak reddish violet colour (Fig. 1), but it is not stable. The result in the epithelial region is hardly determined negative or positive. The authors considered it should be half negative and half positive $( \pm)$.

b) The xanthoproteic reaction (Fig. 2). (Protein containing tyrosine, tryptophan or phenylalanine give a bright orange colour.)

Place sections in cold conc. $\mathrm{HNO}_{3}$, they become yellow, then wash in water, next expose to the fumes of ammonia.

Mucosa in the section gives a weak positive colour in all regions, but in the epithelium it is particularly remarkable (Fig. 2).

These two reactions are well employed for the demonstration of protein. Epithelium of the gastric mucosa gives almost a negative result by the biuret reaction and a positive one by the xanthoproteic reaction. As a substance which gives a positive result by the former reaction must be polypeptide or protein, a substance which gives a half positive and half negative result by the biuret reaction and gives a considerable positive result by the xanthoproteic reaction seems to be likely a conjugation of a few amino-acids or an amino-acid alone.

c) The MILLON's reaction (Fig. 3).

1. Modificated method. (Tyrosine-phenol group-is stained reddish.)

Drop $\mathrm{H}_{2} \mathrm{SO}_{4}$ added $\mathrm{HgSO}_{4}{ }^{*}$ to sections placed on a slide glass, heat for 30 sec. Then add 1 or 2 drops of $1 \% \mathrm{NaNO}_{2}$ and heat gradually.

* To 30 cc destilled water add 10 cc conc. $\mathrm{H}_{2} \mathrm{SO}_{4}$. To $10 \mathrm{~g} \mathrm{HgSO}_{4}$ add it gradually. Then add water to $100 \mathrm{cc}$.

Mucosa of the section gives a orange-red colour, especially the subnuclear portion of the epithelial cells it is plainly visible (Fig. 3).

2. The modification after BENSLEY and GERSH. (Protein containing tyrosine stains orange to rose red.)

Place sections in absolute aceton and remove on a slide glass. Allow to dry in air. Drop the MILLON's reagent on the sections and stand at room temperature for $30-60 \mathrm{~min}$. Rinse in $2 \% \mathrm{HNO}_{3}$ then in water.

Section gives orange red colour and it is similar to that of the above modification 1.

The results of the MILLON's reaction seem to be positive but it is not a typical positive colour in the epithelial region. (In tunica muscularis of the section, a typical positive colour can be seen.) So the authors tested with the other reaction for the tyrosine-research.

d) The PAULY's diazo-reaction (Fig. 4). React diazobenzensulfonic acid and $\mathrm{Na}_{2} \mathrm{CO}_{3}$ to tyrosine, the red azo-dyes are produced. This is the reaction. The authors have employed $2 \%$ solution of them.

The epithelial region in the section gives a considerable positive colour (Fig. 4). However it must be noticed that this reaction gives a positive result not only with tyrosine (phenol group) but also with histidine (imidazol group).

When these four reactions tested by the authors were considered as the pure 
chemical colour reaction, based on the special chemical group of amino-acid, the result are summarized as the following table and tyrosine, tryptophan and histidine come into the discussion-object.

Table 1.

\begin{tabular}{|c|c|c|}
\hline Reaction & $\begin{array}{l}\text { The objective substance of the } \\
\text { positive result }\end{array}$ & $\begin{array}{l}\text { The authors' } \\
\text { result }\end{array}$ \\
\hline The biuret reaction & Polypeptide, protein & \pm \\
\hline The xanthoproteic reaction & Tyrosine, tryptophan, phenylalanine & + \\
\hline The MILLON's reaction & Tyrosine & + (weak) \\
\hline The PAULY's diazo-reaction & Tyrosine, histidine & + \\
\hline
\end{tabular}

e) The COLE's aldehyde reaction (Fig. 5). This is well employed for the research of indol group contained in tryptophan. (Tryptophan stains blue violet.)

Place sections in dil. formalin liquid, put them on a slide glass. Drop on the sections a few drops of $\mathrm{H}_{2} \mathrm{SO}_{4}$ added $\mathrm{HgSO}_{4}$ (cf. the MILLON's reaction, 1) and then conc. $\mathrm{H}_{2} \mathrm{SO}_{4}$.

Result is shown in Fig. 5; it gives no positive colour in the epithelial region.

f) The tetrazonium reaction (Fig. 6). (Tyrosine, tryptophan or histidine stain reddish brown.)

Place sections in water, immerse in freshly tetrazotized benzidine at $4^{\circ} \mathrm{C}$ for 15 min., wash in water and three changes of veronal acetate at $\mathrm{pH} 9.2$ for 2 min. in each change, immerse in saturated solution of $\mathrm{H}$-acid in veronal acetate buffer at $\mathrm{pH} 9.2$ for $15 \mathrm{~min}$., and then wash in water for a few minutes.

The epithelial region, especially subnuclear portion of the epithelial cells, gives a reddish brown colour as it is shown in Fig. 6 .

DANIELLI (1947, 1950) suggested that the three amino-acids, tyrosine, tryptophan and histidine, can be distinguished separately by the use of the tetrazonium reaction followed the 'blocking' reaction with 2,4-dinitrofluorobenzene (DNFB), performic acid and benzoyl chloride. The authors tested them as follows.

g) The tetrazonium reaction after 2,4-DNFB treatment.

Place sections in absolute acetone, remove and allow to dry in air. Treat with a cold $\left(0^{\circ}-4^{\circ} \mathrm{C}\right)$ saturated solution of DNFB in $90 \%$ ethylalcohol saturated with $\mathrm{NaHCO}_{3}$, about $16 \mathrm{hrs}$. Wash in three changes of $90 \%$ alcohol, then in water. Proceed to the tetrazonium reaction mentioned above.

The section gives reddish brown colour. Under the microscope, over-half of the epithelial cells stain yellow-orange and the other-half a clear reddish brown. This differentiation in the epithelium is more distinguishable than that in the case of the tetrazonium reaction alone (Fig. 6).

h) The tetrazonium reaction after performic acid treatment.

Add to $40 \mathrm{cc}$ of $98 \%$ formic acid $4 \mathrm{cc}$ of $30 \% \mathrm{H}_{2} \mathrm{O}_{2}$. Allow the mixture to stand for at least $60 \mathrm{~min}$. before using. Then put sections in the above solution, $10 \mathrm{~min}$. later wash in water. Then proceed with the tetrazonium reaction. 
The section stains reddish orange, but in the epithelial region a reddish brown colour can be seen. Under the microscope, the latter is clearly identical with the result obtained by the tetrazonium reaction alone (Fig. 6).

i) The tetrazonium reaction after benzoyl chloride treatment.

Place sections in petroleum ether for $3 \mathrm{~min}$. Remove and allow to dry in air. Heat at $60^{\circ} \mathrm{C}$ during $5-6$ min. Place the dry sections in $10 \%$ benzoyl chloride in dry pyridine for about $16 \mathrm{hrs}$. at room temperature. Rinse in absolute acetone and then in absolute alcohol. Put sections in water. Proceed to the tetrazonium reaction.

The sections stain orange-yellow. The epithelial region of the mucosa gives also an orange-yellow or a weak orange colour. It is definitely a negative colour.

According to the DANIELLI's suggestion, tyrosine, tryptophan and histidine are blocked as in the following table.

Table 2. The coupled tetrazonium reaction (blocking and eliminating reagents).

\begin{tabular}{l|c|c|c|c}
\hline Substance & Alone & After 2,4 DNFB & $\begin{array}{c}\text { After performic } \\
\text { acid }\end{array}$ & $\begin{array}{c}\text { After benzoyl } \\
\text { chloride }\end{array}$ \\
\hline $\begin{array}{l}\text { Tyrosine } \\
\text { Tryptophan }\end{array}$ & + & - & + & - \\
Histidine & + & + & - & - \\
\hline $\begin{array}{c}\text { The authors' } \\
\text { results }\end{array}$ & + & + & + & - \\
\hline
\end{tabular}

Here the authors' results obtained from the reactions $\mathrm{f}, \mathrm{g}, \mathrm{h}$ and $\mathrm{i}$ will demonstrate that the positive colour after the tetrazonium reaction (Fig. 6) is due to histidine, because tyrosine must be eliminated by 2,4-DNFB and tryptophan by performic acid. [The lack of tryptophan was already demonstrated with the COLE's aldehyde reaction - a positive colour was not seen (Fig. 5).J That is, the substance which exists in the subnuclear portion of the gastric surface cells can be restricted within an amino-acid containing an imidazol group or an analogical substance of it. The authors, therefore, tested a further series of colour reaction which peculiar to an imidazol group.

j) The TOT ANI's reaction (Fig. 7).

1. The lst reaction.

To $10 \% \mathrm{Na}_{2} \mathrm{CO}_{3}$ solution add plenty of diazobenzensulfonic acid. The solution is dropped on the section. The section, especially the epithelial region, gives a dark red colour. This reaction is, theoretically, similar to the PAULY's diazoreaction, and the result obtained is also similar to the latter reaction (Fig. 4).

2. The 2 nd reaction. (Histidine and histamine give a golden colour.)

To conc. HCI Zn-powder is added, then this is dropped on the section following the 1st reaction. The red colour disappears gradually, more than $15 \mathrm{~min}$. later ammonia is droped on it. The section stains orange-yellow. Under the microscope, it is noticed that the lower half of the epithelium gives a typical golden colour (Fig. 7). 
k) The HANKE-KOESSLER's reaction (Fig. 8). (Histidine and histamine give a pinkish colour.)

I-solution: To conc. $\mathrm{HCl} 45 \mathrm{cc}$ add sulfanilic acid $4.5 \mathrm{~g}$ and add distilled water to $500 \mathrm{cc}$. II-solution; to $\mathrm{NaNO}_{2} 25 \mathrm{~g}$ add water $500 \mathrm{cc}$. To I-solution $1.5 \mathrm{cc}$ add IIsolution $1.5 \mathrm{cc}$, stand in ice water for $5 \mathrm{~min}$., then add to it II-solution $6 \mathrm{cc}, 5 \mathrm{~min}$. later add distilled water to $50 \mathrm{cc}$. More than 15 min. later, add $1.1 \% \mathrm{Na}_{2} \mathrm{CO}_{3}$ solution $5 \mathrm{cc}$ to the above mixture $2 \mathrm{cc} .1 \mathrm{~min}$. later it drops on the sections.

The subnuclear portion of the epithelial cells gives a pinkish yellow colour (Fig. 8), and no typical pink one. It must be noticed, however, that the solution of histamine hydrochloride gives also a pinkish yellow colour, when tested in vitro. According to these two reactions ( $j$ and $k$ ), an imidazol group was confirmed positively.

A substance containing an imidazol group, which was determined after several reactions mentioned above, must be histidine or histamine. But it is difficult to distinguish histidine and histamine by chemical colour reactions, because they differ from each other only in their side chaine. The authors, therefore, will study further on other colour reactions and other suitable methods to separate histidine, histamine and other substances containing an imidazol group.

\section{Summary.}

In order to demonstrate histochemically the content of the productin vacuoles which are seen in the subnuclear portion of the surface cells of the gastric mucous membrane and named by FUJIE 1952, eleven colour reactions for protein and amino-acids were tested on the freezed sections of the dog's stomach fixed by formalin. The test proved that plenty of such substance as an amino-acid containing an imidazol group (like histidine) or, leastways, an analogical substance of it (like histamine) is contained in the surface cells, especially in their subnuclear portion. This portion is the one in which the productin vacuoles are seen.

\section{内 容自 抄。}

藤江の提唱したヒスタミン様の胃壁ホルモン productin の本態を更に明確にし たいと考光, 胃粘膜表在細胞飞含まれる productin 空胞の内容を組織化学的飞決 定出来奴々試みたのが本篇である。即ち空腹犬胃壁をフォルマリン固定し，

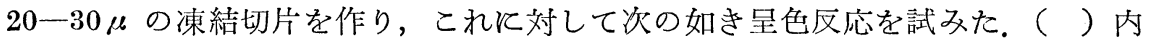
は陽性または陰性の結果を示す。

1. ビウレット反応 $( \pm), 2$. キサントプロテイン反応 $(+), 3$. Millon 反応 変法 (十弱), Bensley-Gershの変法 (十弱), 4. Paulyのヂアゾ反応 $(+)$, 5. Cole のアルデヒド反応 $(-), 6$. テトラゾニウム反応 $(+)$ ， 7. 2,4-ヂニトロフルオロ ベンゼン前処理後テトラゾニウム反応 $(+), 8$. 過蟻酸前処理後テトラゾニウム 反応 $(+), 9$. 塩化ベンゾイール前処理後テトラゾニウム反応 $(-)$, 10. Totani の反応, 第 1 反応 $(+)$, 第 2 反応 (黄金色の + ), 11. Hanke-Koessler の反応 (桃 黄色の+). 
以上の結果，胃粘膜表在細胞，殊にとの下半部にはイミダゾール核を有するア ミノ酸（ヒスチデンの如き）か，これに類似の構造をもつ物質（ヒスタミンの如 き）が多量存在することが証明された。 その位置は productin 空胞の存在する部 位と一致し, 従って productin がヒスタミンか, これに近い物質であることや, productin が胃粘膜表在細胞から内分泌されることを間接的な実験成績から主張 していた藤江の説はかなり真実近いものと考劣られる。

\section{References.}

Danielli, J. F.: Cytochemistry. London, 1953. - Fujie, K.: On a new gastric hormone, proposed to be named 'productin'. Wakayama Med. Rep. 1 (1953). - Fujie, K. et al.: On the images of endocrine function in the surface cells of the gastric mucous membrane. Arch. hist. jap. 4 (1952). - Cytological studies on the cause of pancreatic secretion. IV. On gastric hormone proposed to be named 'productin'. Arch. hist. jap. 3 (1952). - V. On the true nature of 'productin (FUJIE)'. Arch. hist. jap. 4 (1953). - Again on the true nature of 'productin'. Arch. hist. jap. 6 (1954). - Fujii, Y.: Biochemical method. (The qualitative determination.) Tokyo, 1947. - Ichikawa, O.: Cytochemistry. Tokyo, 1953.

- Okamoto, K. et al.: Microscopic histochemistry. Tokyo, 1955. - Pearse, A. G. E.: Histochemistry. London, 1955. 
Plate-figures. 


\section{Explanation of Plate.}

Fig. 1. The biuret reaction. The mucosa gives a very weak reddish violet colour. The result in the epithelial region has been considered half negative and half positive ( \pm ).

Fig. 2. The xanthoproteic reaction. The mucosa gives, generally, a weak positive colour but in the epithelial region it is particularly remarkable.

Fig. 3. The MILLON's reaction. Modificated method by using $\mathrm{H}_{2} \mathrm{SO}_{4}$ added $\mathrm{HgSO}_{4}$ and $\mathrm{NaNO}_{2}$. The subnuclear portion of the epithelial cells gives a remarkable reaction, but a colour is not a typical positive one.

Fig. 4. The PAULY's diazo-reaction. The epithelial region gives a considerable positive colour.

Fig. 5. The COLE's aldehyde reaction. The epithelial region gives no positive colour.

Fig. 6. The tetrazonium reaction. Subnuclear portion of the epithelial cells gives, especially, a reddish brown colour.

Fig. 7. The TOTANI's reaction. (The 2nd 7eaction). The lower half of the epithelium gives a golden colour. Histidine and histamine (imidazol group) stain gold.

Fig. 8. The HANKE-KOESSLER's reaction. Subnuclear portion of the epithelial cells gives a pinkish yellow colour. A typical positive colour related with histidine or histamine is said pink, but the solution of histamine hydrochloride gave also a pinkish yellow colour when the authors tested it in vitro. 
K. FUJIE, T. YAMASHITA, K. TOJYO and I. YAMAGATA.

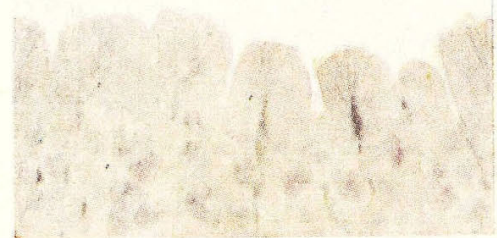

1

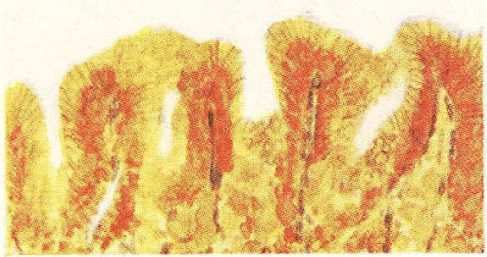

3

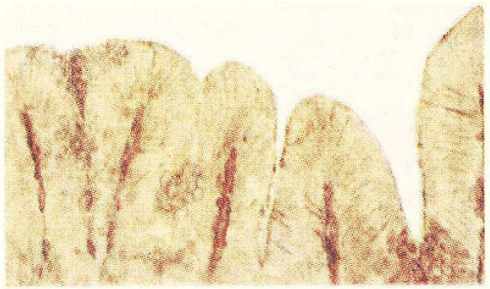

$\bar{\jmath}$

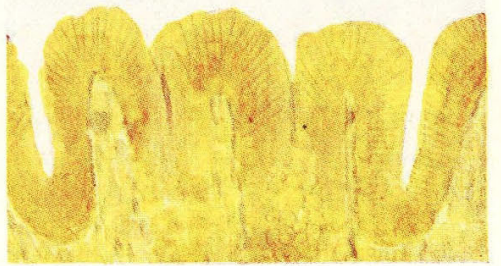

7

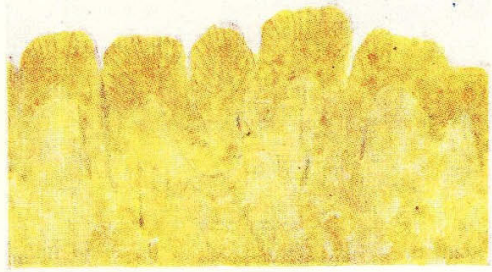

2

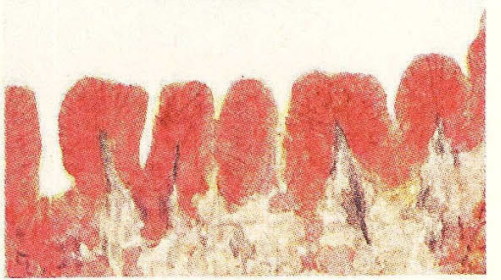

4

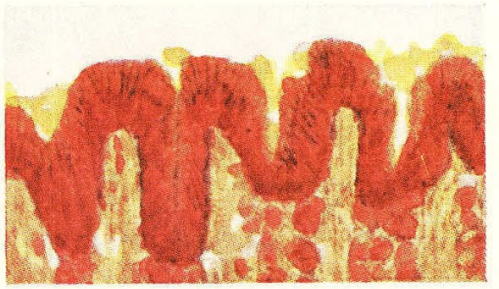

6

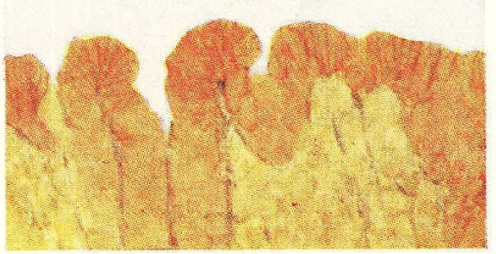

8 